OTHER WORLDS 



\section{Other Worlds}

Spirituality and the Search for Invisible Dimensions

CHRISTOPHER G. WHITE

HARVARD UNIVERSITY PRESS

Cambridge, Massachusetts \& London, England / 2018 
Copyright (c) 2018 by the President and Fellows of Harvard College All rights reserved Printed in the United States of America

First Printing Library of Congress Cataloging-in-Publication Data

Names: White, Christopher G., 1969- author. Title: Other worlds : spirituality and the search for invisible dimensions / Christopher G. White. Description: Cambridge, Massachusetts : Harvard University Press, 2018. | Includes bibliographical references and index. Identifiers: LCCN 2017041042 | ISBN 9780674984295 (hardcover : alk. paper) Subjects: LCSH: Religion and science-United States. | Religion and science-Great Britain. | Arts and religion-United States. | Arts and religion-Great Britain. | Fourth dimension. | Hyperspace. Classification: LCC BL240.3.W485 2018 | DDC 201/.65-dc23

LC record available at https://lccn.loc.gov/2017041042

Cover design: Graciela Galup

Cover art: agsandrew / Thinkstock 
For Tracy 
